\title{
Академик Ф. И. Буслаев \\ и его «Историческая христоматия церковно- славянского и древнерусского языков»
}

\author{
К 200-летию со дня рождения ученого
}

\begin{abstract}
О. В. НИКИТИН
O. V. NiKITIN, Кафедра истории русского языка и общего языкознания, Московский государственный областной университет, ул. Радио, д. 10a, RU-105005 Москва Department of History of Russian and General Linguistics, Moscow Region State University E-mail: olnikitin@yandex.ru
\end{abstract}

(Received: 12 June 2018; accepted: 14 September 2018)

\begin{abstract}
An analytical overview of the famous work by F. Buslaev "A Historical Anthology of Church Slavonic and Old Russian" is offered. The facts of its creation are given. The structure and the content of the work are considered. Its role in the formation of the professional culture of philologists and its influence on the subsequent tradition of the preparation of historical and linguistic textbooks is noted. Special emphasis is placed on the scientific value of the first complete textbook of historical written documents and the tradition that was developed after Buslaev's publication.
\end{abstract}

Keywords: Slavic studies, history of linguistics, written documents, folk literature, educational culture

Постепенное раскрытие дара слова и законов оного должно быть вместе и раскрытием всех нравственных сил учащегося: ибо родной язык есть неистощчимая сокровищница всего духовного бытия человеческого (БУСЛАЕВ 1844: III).

В 2018 году филологический мир отмечает памятную дату - 200-летие со дня рождения Федора Ивановича Буслаева (1818-1897) - ученого редкого дарования и удивительных свойств неподражаемой личности, вся жизнь которого была направлена на служение науке в самом высоком смысле этого слова. Он и до сих пор стоит одним из первых в ряду просветителей-гуманитариев как уникальный культурный феномен, как охранитель традиции и ее верный рыцарь.

Имя академика Ф. И. Буслаева, знатока и издателя памятников народной культуры, педагога-новатора, вдохновлявшего своим живым примером и любовью к словесности не одно поколение учителей, уже давно вписано в историю славянского языкознания как первопроходца компаративистики наряду с именами Й. Добровского, Ф. Боппа, Я. Гримма, А. Х. Востокова. Его 
магистерская диссертация, посвященная анализу языка Остромирова Евангелия, показала возможности применения сравнительной методики к изучению древней символики и выявлению скрытых смыслов языческой и христианской культуры (БуслАЕВ 1848).

Еще с ранних лет Ф. И. Буслаев был увлечен историей. Гуманистический принцип (в противовес техническому, или, как раньше говорили, «реалистическому») он применял и в методике обучения русскому языку, когда призывал к сравнительному анализу явлений грамматики и стилистики (см. БусЛАЕВ 1844).

Среди многочисленных трудов Ф. И. Буслаева по филологии есть и такие работы, которые, на первый взгляд, стоят особняком в лингвистической «биографии» того времени. Между тем именно они сформировали то самое «памятниковедческое» направление в культурной традиции России, которое позволило отойти от «полицейских» правил грамматики и проникнуть в языковой организм посредством общения с живыл словом на примерах лучших образцов устной и письменной народной культуры.

«Историческая христоматия церковно-славянского и древнерусского языков» занимает особое место в учебной и научной литературе XIX века (БуслАЕв 1861). Она была выпущена как раз в период становления национальной системы филологического образования, все больше обращавшего внимание на пользу изучения исторических памятников, народной архаики, песен, сказаний, рукописей духовного и светского содержания. Многие из них хранились долгие годы под спудом архивов и библиотечных собраний. Ф. И. Буслаев словно подхватил призыв академика А. Х. Востокова издавать памятники старины, открывать уникальные собрания древностей, сделать их достоянием общественности, включить эти факты в контекст научных дискуссий и позволить прикоснуться к редким документам и произведениям народного творчества широкой аудитории читателей, воспитывать их в новых просветительских традициях и прививать им любовь к Отечеству.

До Ф. И. Буслаева известностью пользовались хрестоматии А. Д. Галахова (см., например, 3-е издание: ГАЛАхов 1846-1849, а также: ГАЛАХов 1848). Тот же автор издавал свои работы и по поручению военного ведомства. Об этом, в частности, упоминал и Ф. И. Буслаев на страницах своего «Опыта исторической грамматики русского языка» (БуслАЕВ 1858).

В начале 1850-х годов Ф. И. Буслаев задумал подготовить «на основании наставления для образования воспитанников военно-учебных заведений, высочайше утвержденного 24 декабря 1848 года» два больших труда: первый впоследствии получил название «Опыт исторической грамматики русского языка» (БуслАЕВ 1858), а второй - «Историческая христоматия...» (БуслАЕв 1861). Это требовало от ученого не только основательных знаний по «памятниковедению», но и поисков редких источников, их отбора и расшифровки, систематизации материала. Такая кропотливая работа продолжалась около десяти лет. К середине 1850-х годов в целом была готова концепция «русской грамматики сравнительно со словенскою», как называл ее 
Ф. И. Буслаев в письме к В. И. Григоровичу от 8 марта 1855 года. С душевным волнением он сообщал о невероятных трудностях в подготовке этого издания:

...однако скажу Вам, что были у меня такие времена, что не только не мог писать писем, но мало говорил, и это случалось по нескольку месяцев. Года два тому назад я чувствовал себя в страшной пытке, когда, изготовив 1-ю часть русской Грамматики, сравнительно со словенскою, я почувствовал живо, сколько еще нужно приуготовить работ для того, чтобы составить учебник, на основании современных требований науки, в том идеальном совершенстве, которое чувствуется, но которого привести в исполнение нет возможности (ОР РГБ. Ф. 28. Картон 4. Ед. хр. № 28. Лл. 5 об.-6).

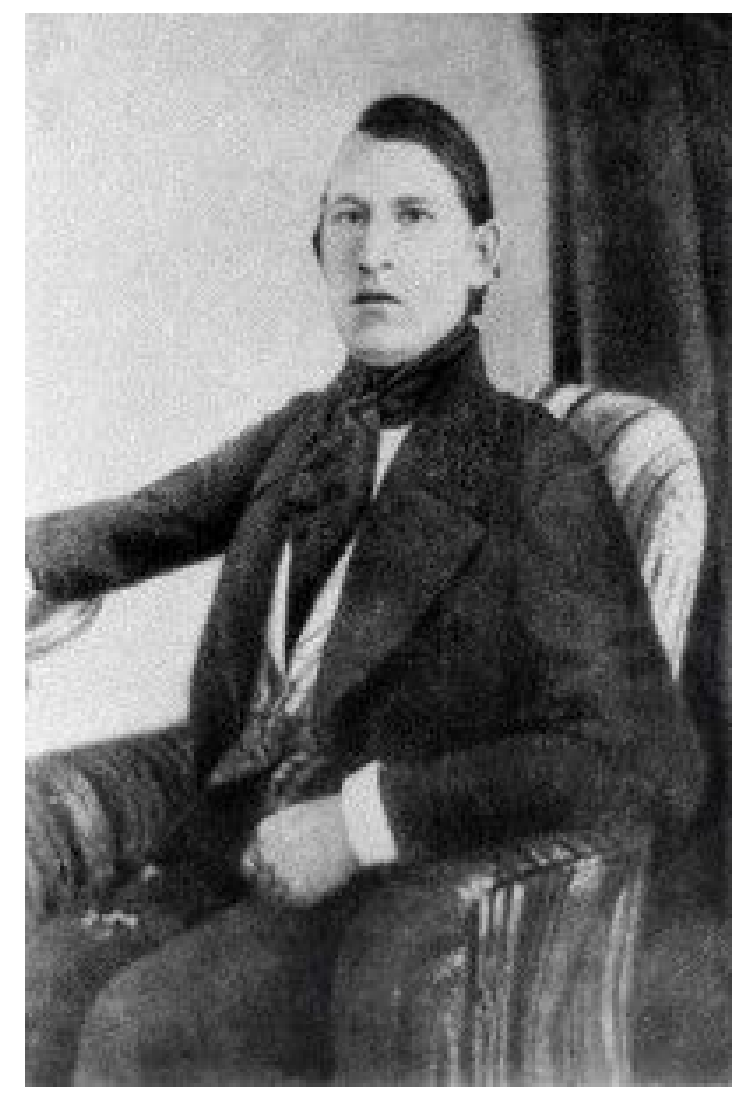

Федор Иванович Буслаев.

С литографии предположительно начала 1840-х гг.

Из письма Ф. И. Буслаева В. И. Григоровичу понятно, что эта работа растянулась на несколько лет: в начале ее ученый готовил первую часть «Опыта исторической грамматики», которая была задумана в русле новых компаративистских тенденций в науке тех лет - то, чем он «заразился»еще 
в молодости от своих учителей И. И. Давыдова, М. П. Погодина и др., открывая для себя труды основоположников сравнительного изучения языков В. фон Гумбольдта, Я. Гримма, Ф. Боппа.

Затем Ф. И. Буслаев разрабатывал вторую часть - синтаксис. Вот как он писал об этом В. И. Григоровичу в том же послании:

Гораздо легче было мне работать над 2-ю частью, т. е. над Синтаксисом, хотя и приходилось почти на каждом шагу прорубать новый путь в темном лесу страшной груды выписок, начиная от рукописей XI в. и до Жуковского и Пушкина включительно (ОР РГБ. Ф. 28. Картон 4. Ед. хр. № 28. Л. 6).

Потом Ф. И. Буслаев принялся за работу над собранием текстов памятников церковной, деловой и народной словесности, имея уже значительный практический опыт использования рукописного материала и изданных документов для учебных и научных целей. Он поделился своими сокровенными мыслями с близким по духу соратником - славистом В. И. Григоровичем:

...вслед за Грамматикой, тружусь для военно-учебных [заведений] над составлением Хрестоматии церковно-славянского и древнерусского языка. У меня накопился богатый запас статей по рукописям [взятое в квадратные скобки слово восстанавливается нами предположительно, в тексте письма оно замазано кляксой - О. Н.] (ОР РГБ. Ф. 28. Картон 4. Ед. хр. № 28. Л. 6 об.).

Это действительно так: Ф. И. Буслаев отлично знал особенно московские библиотеки и хранилища и находился в кругу просвещенных филологов, библиографов, архивистов, которые в той или иной мере помогали ученому и направляли его исследовательские поиски. В их числе в «Предисловии» к «Исторической христоматии» он с благодарностью упоминал О. М. Бодянского, А. Ф. Бычкова, А. Е. Викторова, А. В. Горского, В. И. Григоровича, И. Е. Забелина, князя М. А. Оболенского, А. Н. Пыпина, синодального ризничего архимандрита Савву, графа С. Г. Строганова и Н. С. Тихонравова.

Итак, в 1861 году была напечатана внушительная в 1632 столбца «Историческая христоматия» Ф. И. Буслаева. В «Предисловии» к своему труду ученый писал:

...Историческая христоматия церковно-славянского и древнерусского языков имеет двоякое назначение: во-первых[,] служит руководством к изучению этих языков и, во-вторых, предлагает образцы для древнего периода истории нашей словесности. В первом отношении эта Христоматия состоит в связи с Опытом исторической грамматики русского языка, во втором с Историею русской литературы г. Галахова, принятою в числе учебных руководств для военно-учебных заведений (БУсЛАЕВ 1861: I).

Книга состояла из двух больших разделов - «отделений». В первом Ф. И. Буслаев поместил отрывки из Священного Писания и богослужебных книг, «начиная с древнейших письменных памятников до исправленного текста Библии» (БуслАЕВ 1861: I). Во втором содержались другие произведения 
церковно-славянской и древнерусской литературы. Все памятники Ф. И. Буслаев расположил в хронологическом порядке, с XI по XVI вв. в «Отделе первом», и с XI по XVII вв. в «Отделе втором».

Кроме того, большой интерес для фольклористов и диалектологов представляют также два приложения к «Исторической христоматии»: «Памятники народной словесности XVIII в.» и «Образцы современной народной словесности».

Важной особенностью этой энциклопедии письменной культуры является публикация новых текстов, которые значительно обогатили свод уже имеющихся изданий и в таком объеме в книге учебного характера выпускались впервые. Для Ф. И. Буслаева было важно не только показать определенный стандарт жанра, так сказать, канонический стиль эпохи, но и дать своим читателям представление о богатстве словесно-изобразительных красок, расширяющих сведения о языке древних памятников. Потому, например, в «Отделе первом» наряду с востоковским изданием «Остромирова Евангелия» он поместил отобранные специально для своей «Исторической христоматии» тексты толковой Псалтири, галицкого списка Евангелия, служебников Антония Римлянина, Варлаама Хутынского и митрополита Киприана, разные списки библейских книг и сборников религиозного содержания. Этот «Отдел» по преимуществу и составили новые тексты, изданные автором впервые.

Ф. И. Буслаев снабжал свои публикации качественным и весьма подробным палеографическим, историческим, лингвистическим комментарием, указывая разночтения, нюансы графического орнамента, передачу звуков на письме, особенности использования грамматических форм и т. д. Ученый также давал общую лингвокультурную оценку памятнику и разъяснял элементы его структуры и текстологии. Например, комментарий к публикации глав из «Остромирова Евангелия» открывается такой фразой:

Остромиров список Евангелия из всех памятников русской письменности в наибольшей чистоте удержал особенности древнейшего болгарского текста, с которого был списан. [...]

Русских особенностей встречается больше в Послесловии и в Синаксарии, нежели в самом тексте Евангелия.

Это Евангелие Недельное (Апракос), то есть расположенное не по евангелистам в последовательном порядке глав, а по неделям, начиная с Пасхи. Между текстами Евангелия помещен Синаксарий, то есть краткое извещение о праздниках и святых, расположенное по неделям и месяцам (БуслАЕВ 1861: 12-13).

Издавая текст из сборника, принадлежавшего Императорскому московскому обществу истории и древностей российских («Притчи Соломоновы»), ученый замечал, что

...он отличается признаками глубокой древности, как это явствует из сличения его с исправленным. Правописание отличается особенностями болгарского оригинала, с которого списывал русский писец. Употребляются юсы, хотя и не всегда правильно... (БуслАЕв 1861: 158-159). 


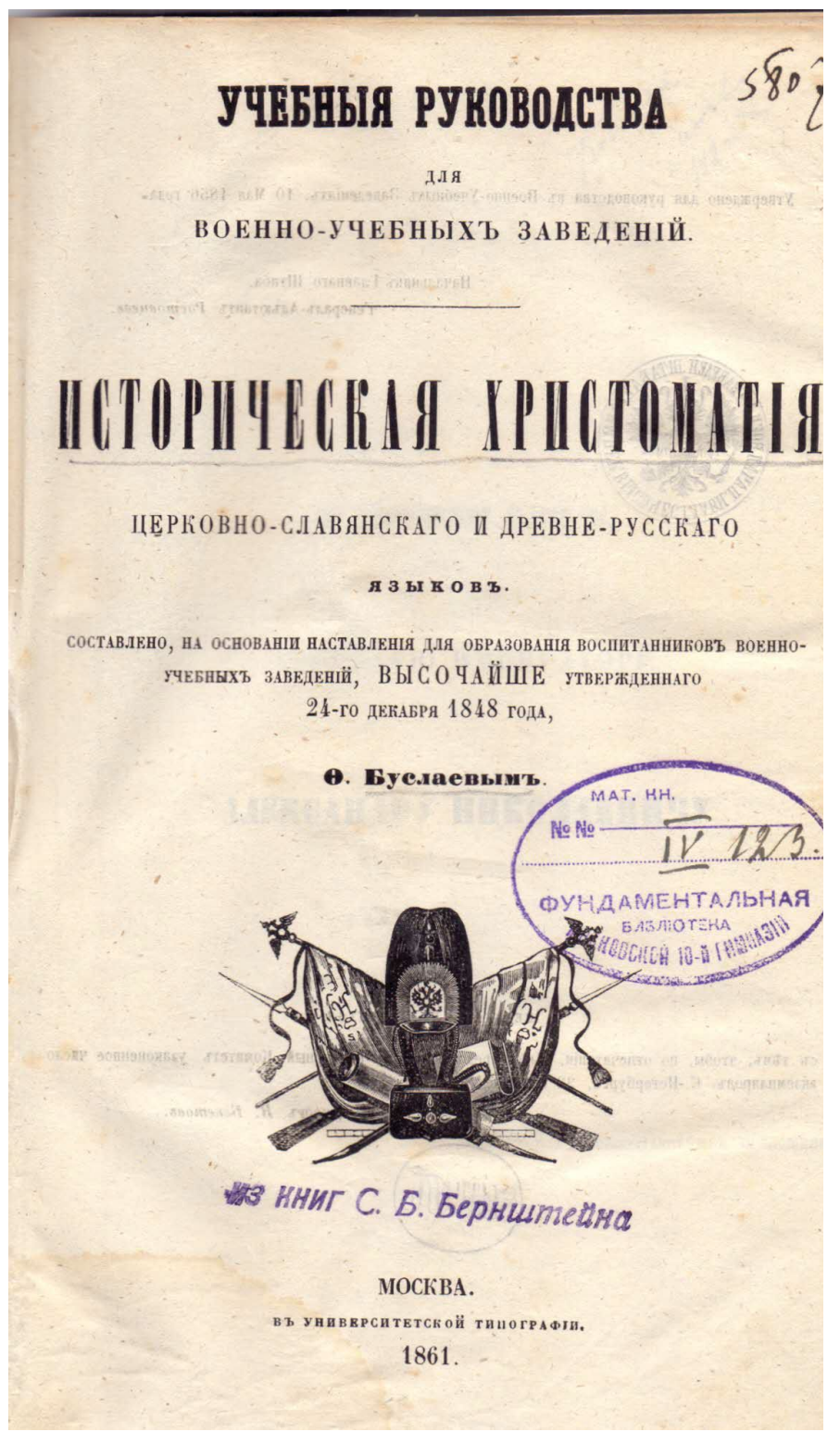

Титульный лист «Исторической христоматии»

Ф. И. Буслаева (Москва, 1861)

«Отдел второй» - лебединая песня вдохновенной буслаевской стихии слова, в которой он смог выразить лучшие свои идеи, дать полноценную панораму древней и новой лингвокультуры текстов. Эта часть, на наш взгляд, наиболее интересна для исследователей и оригинальна, потому что впервые 
представляет всю палитру художественных орнаментов и стилистических рисунков древнерусских памятников, как известных - «Изборника Святослава», «Супрасльской рукописи», «Синайского патерика», списков «Кормчей книги», «Златой Цепи», «Пчелы», «Златоструя», но представленных часто в рукописных подлинниках, так и редких, только входивших в филологическую культуру того времени. К последним можно отнести корпус текстов делового содержания, начиная с «Грамоты великого князя Мстислава Володимировича и сына его Всеволода Мстиславовича» XII в. и завершая судебными «смехотворными» повестями и шутливой челобитной XVII в. В «Исторической христоматии» впервые в таком объеме даются образцы приказной литературы, которая в начале XIX в. в историко-лингвистических целях была изучена слабо и не входила в культурный слой источников (Никитин 2000). Ф. И. Буслаев же, напротив, показал богатство ее жанров и трансформаций, влияние на формирование стилей литературного языка. К числу таких памятников отнесены публикации текстов «Судебника» 1550 г., отчета посла времени Ивана Грозного, духовные грамоты, «Уложение» царя Алексея Михайловича и др. Даже период включительно по XV век, где не было такого разнообразия литературных жанров, освещен Ф. И. Буслаевым очень подробно и познавательно: от летописей и монастырских сборников до «Слова о полку Игореве», «Моления» Даниила Заточника, «Хронографа» 1494 г., хождений и сочинений по физике Земли и телесным наукам.

Полагаем, что исследователям и студентам-филологам XXI века здесь будут полезны прежде всего комментарии ученого к изданным текстам, показывающие живой интерес Ф. И. Буслаева к каждому памятнику, его внимание к деталям, недюжинное филологическое чутье и талант самобытного ученого и педагога. Фрагмент Волынской летописи по Ипатьевскому списку сопровождался таким пояснением:

Волынская летопись отличается от прочих поэтическим изложением и украшенным слогом.

Правописание Ипатьевского списка русское. Местные особенности выговора обозначались в обоюдном переходе звуков $u$ и $4, y$ и в, $b$ и $u$ (БуСЛАЕВ 1861: 577).

Далее автор «Исторической христоматии» разъяснял отдельные слова и выражения, например:

Самодержьца всея Руси: любопытное выражение, важное для истории царско-

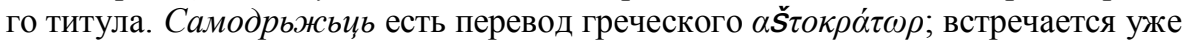
в древнейших славянских памятниках (БуслАЕв 1861: 577).

В другом месте Ф. И. Буслаев почти восклицал:

Замечательно, что для переговоров посылается певец (гудьйь - музыкант). Он должен петь песни половецкие, имеющие чарующую силу убеждения. Если же не подействуют песни, подействует зелье евщанъ (БуслАЕв 1861: 578). 
За публикацией фрагмента «Слова о полку Игореве» следовала целая статья ученого, рассказывавшая об истории нахождения этого уникального памятника и его судьбе, об общих языковых особенностях, о сюжете. Между прочим, он замечал:

...соединение древнейших признаков языка и правописания с позднейшими свидетельствует ясно, что этот памятник дошел до нас в позднейшем списке (XIV-XV вв.), переписанном с древнейшего оригинала (БуслАЕв 1861: 596).

Высокий исследовательский пафос содержат слова Ф. И. Буслаева о Бояне, о художественных достоинствах текста. Он словно проникал в душу неведомого автора:

Поэтическая часть Слова о п<олку> И<гореве> имеет значительное сходство с многими произведениями народной фантазии, особенно с южнорусскими. Трудно сказать, кому принадлежит мифическая часть Слова, самому ли сочинителю или Бояну; во всяком случае для нас важно то, что сочинитель XII в. был только проникнут преданиями мифической старины, что по всему своему произведению распространил суеверное убеждение не только в сочувствии всей природы человеку, но и в чудесной силе и в особенном значении каких-то мифических существ (БуслАЕВ 1861: 598).

Особенно подробно в «Исторической христоматии» представлены произведения XVI и XVII веков - самый пестрый период в истории русского литературного языка допетровского времени, вобравший в себя и черты церковной книжности, и живые образцы народного творчества, и грамматические сочинения, и публицистику. Вызывает безмерное уважение и сейчас внимание Ф. И. Буслаева к «историческим хроникам» языка, запечатленного сразу в нескольких пространствах культуры. Он как будто находился, выражаясь словами Ю. М. Лотмана, «внутри мыслящих миров» - жил со своими героями, сочувствовал им или порицал их, молился за них и ликовал вместе с ними, когда искал «ключ разумения». Ф. И. Буслаев завлекает своих читателей в словесный лимонарь неизведанной поэтики старинных житий, посланий и путешествий.

Наряду с жанрами религиозного характера вроде Четьих Миней здесь представлены такие колоритные с точки зрения культуры языка того времени произведения, как «Домострой», сочинения князя Курбского, великорусские песни в записях Ричарда Джемса, «Лексикон» Памвы Берынды, «Грамматика» Мелетия Смотрицкого и азбуковник, письмо патриарха Никона и «Куранты», «Космография» и сочинения Симеона Полоцкого, «Урядник сокольничья пути» и «Букварь» Кариона Истомина, повести, лечебники, сказания и притчи, апокрифическая литература, получившие распространение в этот период.

По сути дела перед нами целая славянская энциклопедия филологической культуры Отечества в ее лучших образцах. Каждый из них в изображении 
Ф. И. Буслаева получил живые черты узорчатого текста, в котором переплетались разные традиции, практические навыки и духовные чаяния русского народа.

Вот, например, что ученый написал в сопроводительной статье об одном примечательном памятнике деловой литературы XVII в.:

Урядник сокольничья пути есть нечто [так в тексте - О. Н.] иное, как устав соколиной охоты и всего, что к ней относится. Для истории языка и слога этот памятник предлагает много любопытных подробностей в описании быта охотничьего и обрядов или церемоний, сопровождавших охоту. Обрядом определялись не только действия охотников, но и слова их. Слог отличается удивительною наивностью, особенно там, где составитель Урядника выражает, так сказать, свои эстетические воззрения на красоту охотничьих птиц и на тонкое уменье и ловкость охотника (БуслАЕВ 1861: 1275).

Говоря о сочинениях Иоанникия и Софрония Лихудиев (так у Ф. И. Буслаева), автор «Исторической христоматии» указал и на особенности стилистики текста:

В слоге их господствует принятая в то время напыщенность, явствующая уже в самых заглавиях сочинений: Мечещъ духовный, Манна и пр. Слич. щитъ, мечъ, стръла, праща. Язык искусственный, исполненный грецизмов (БуслАЕВ 1861: 1287).

Ф. И. Буслаев еще в ранних своих сочинениях «О преподавании отечественного языка» (БуслАЕв 1844) и «О влиянии христианства на славянский язык. Опыт истории языка по Остромирову Евангелию» (БуслАев 1848) не раз говорил о той высокой духовной силе, о разуме народном, скрывавшихся в таких «безыскусственных» текстах. Для него песни, «всенародные пословицы», древние стихотворения, былины и другие образцы «простой» словесности всегда были теми источниками, с помощью которых он проникал в мифологическое сознание предков, улавливал их душевные переживания, нравственные поиски, видел образы давно ушедших времен, из чего и постепенно слагался, выражаясь словами В. фон Гумбольдта, дух народа. Поэтому и в такой, казалось бы, официальной «Исторической христоматии» он остался верен своему филологическому вкусу и творческому вдохновению певца народной культуры.

В «Приложение І» Ф. И. Буслаев включил фрагменты пословиц 1714 г. по рукописи М. П. Погодина и сборнику 1746 г., отрывки из «Древних российских стихотворений» по изданию Калайдовича 1818 г., наговор, некоторые сказки из авторитетных собраний и изданий Забелина и Сахарова, подблюдные песни и русские стихотворения 1790-1791 гг., хранившиеся в Румянцевском музее. Показательны стихи о Соловее Будимировиче, Дюке Степановиче, Василии Буслаеве, о Садко в поэтическом изложении неизвестных сочинителей, собранные Киршей Даниловым и прокомментированные Ф. И. Буслаевым. 
В «Приложение ІІ» вошли образцы великорусского наречия Архангельской, Вологодской, Олонецкой, Ярославской и Нижегородской губерний, хороводная песня «закамского наречия», говоры Южной Сибири, духовные стихи. Заключительные страницы издания посвящены краткому обзору элементов белорусского и малорусского (Ф. И. Буслаев употреблял такой термин, принятый в его время) наречий. В этой части он также помещал необходимые комментарии к текстам. Так, например, после публикации сказки, представлявшей собой образец вытегорского наречия Олонецкой губернии, Ф. И. Буслаев заметил:

Особенности этого наречия: 1) $u$ вм. 4 ; 2) $u$ вм. $b$, особенно в слове $8 c u$; 3) миня, сиби вм. меня, себъ; 4) си и се вм. ся; 5) іонъ, іоны вм. онъ, они; 6) ярда вм. apдa, т. е. орда (в смысле земли, страны); 7) ма́тышка вм. матушка; 8) в род. пад. ед. Ч. -ого вм. -аго» (БуСЛАЕВ 1861: 1586).

В качестве хрестоматийных материалов для изучения истории русского языка такие тексты исключительно ценны как фрагменты языковой картины мира народа в его бытовом и этнографическом выражении.

XVIII век в основную часть «Исторической хрестоматии» не вошел. Отдельные образцы текстов в небольшом количестве помещены автором в приложениях. Видимо, для середины XIX столетия, когда создавался этот труд, сочинения А. Д. Кантемира, В. К. Тредиаковского, В. Е. Адодурова (о нем см., например, Никитин 2009: 104-110), М. В. Ломоносова, А. П. Сумарокова и других филологов и грамматистов не воспринимались как проповедники и слагатели старинной литературы. Это была уже новая традиция, реформировавшая древнюю словесность и вводившая другие правила.

Е. Ф. Будде в памятной речи «О заслугах Ф. И. Буслаева как ученого лингвиста и преподавателя» сочувственно замечал:

После «Грамматики» в 1861-м году Буслаев издал свою знаменитую «Христоматию» в качестве учебного руководства для военно-учебных заведений. Мы опять здесь имеем дело с тем обстоятельством, что Буслаев пишет свои руководства для военно-учебных заведений, управление которых, как мы помним, оценило раньше других лиц преподавательские заслуги Буслаева и поручило ему составить план преподавания русского языка и словесности. «Христоматия» Буслаева есть ценное всеподданнейшее приношение Его Императорскому Величеству Государю Императору Александру Николаевичу. Эта Христоматия представляет из себя такой громадный и крупный по своему значению ученый труд, что уже вскоре не могли без него обходиться ученые специалисты, жившие вдали от главных книгохранилищ и рукописных собраний России. В этой Христоматии помещены отрывки рукописных и старопечатных сочинений и редких изданий из разных книгохранилищ России и расположены в хронологическом порядке так, что всякий занимающийся языком и литературой может следить по этой Христоматии за развитием и изменением русского литературного языка на всем пространстве России, где только была в древности литературная деятельность... В этой Христоматии многие памятники изданы впервые 
в России, и мы по ней можем следить за областными изменениями языка, поскольку последние отражались в письменности. Кроме того, каждый отрывок снабжен в Христоматии Буслаева его примечаниями лингвистическими и историко-литературными (БуддЕ 1898: 21).

Действительно, работа, проделанная ученым в одиночку, была бы по силам нескольким работникам. Однако Ф. И. Буслаев взялся сам за такой колоссальный труд, потребовавший от него энциклопедических познаний практически во всех отраслях гуманитарных наук: древней истории и религиоведения, палеографии и археологии, этнографии и диалектологии, эстетики, философии, психологии народного творчества, не говоря уж собственно о филологических методах, которые получили блестящее исполнение под талантливым пером Ф. И. Буслаева.

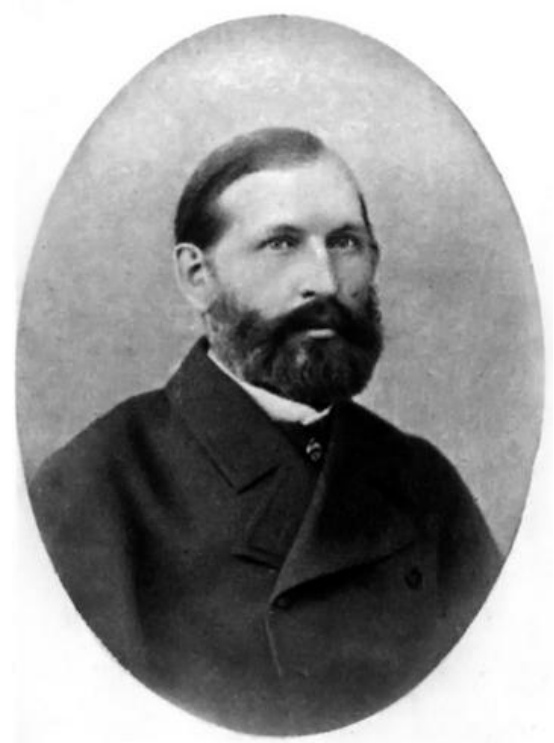

Федор Иванович Буслаев. Фото 1865 г.

Академик А. А. Шахматов в статье «Буслаев как основатель исторического изучения русского языка» с большим уважением отозвался об этой работе ученого:

Особенно ярко обнаружится значение Исторической грамматики Буслаева, если мы взглянем на изданную им в 1861 году Историческую христоматию церковно-славянского и древнерусского языков. По мысли автора, христоматия эта должна была служить между прочим руководством при изучении этих языков: для этого она поставлена в связь с Опытом исторической грамматики. Христоматия содержит в себе тексты, взятые большею частью прямо из рукописей и 
напечатанные с удержанием всех особенностей древнего правописания, тексты эти относятся к XI-XVII веку. Таким образом, по христоматии можно наглядно изучать все те изменения, которым подвергалась в течение веков наша письменность. В приложениях приведены в высшей степени важные по своему научному значению памятники народной литературы XVIII в., а также образцы современной устной народной словесности. В примечаниях к каждому изданному тексту находим указание на все важнейшее в историческом изучении языка и литературы. «Таким образом, - говорит Буслаев, - совокупность всех примечаний, расположенных в хронологическом порядке памятников, составляет как бы историю языка и письменности в практическом изложении» [здесь и далее полужирный курсив - О. Н.]. В этих примечаниях Буслаев не был стеснен школьными рубриками и на живых примерах, действительных фактах, извлеченных из первоисточников, показал, что дает древний текст или современная разговорная речь для научной грамматики языка, Буслаев научил вместе с тем будущих исследователей, как следует оживить мертвую букву, как заставить старинную хартию или полуистлевший пергамен давать свидетельские показания о жсивом произношении минувших веков, о звуковом и грамматическом строе древнего языка. На изданных и разобранных текстах Буслаев показал, что изучение русского языка должно быть основано на исследовании древних и современных образцов языка, что грамматика не предписывает законов словоупотребления, а что она прежде всего регистрирует факты языка и затем дает им сравнительно-историческое освещение. Таким образом, Буслаев дал нам два издания русской исторической грамматики: в одном из них видим школьное, теоретическое изложение особенностей русской речи, в другом - практическое и научное переложение того же предмета (ШАХмАТОВ 1898: 15-16).

«Историческая христоматия» Ф. И. Буслаева - целая веха в лингвистическом «памятниковедении» России. Среди достоинств этой книги, отмеченных современниками и учениками Федора Ивановича, было высказано и такое мнение:

Множество неизданных раньше памятников вошло и в его известную Историческую хрестоматию [так у В. Ф. Миллера; правильно: христоматию - О. Н.] церковно-славянского и древнерусского языков (М., 1861), с многочисленными примечаниями историко-литературными и лингвистическими, что делает эту обширную и давно вышедшую из продажи книгу до сих пор незаменимым пособием для изучения образцов языка (МиллЕР 1898: 28).

Но и после такого успеха, когда тщанием Ф. И. Буслаева были опубликованы, прокомментированы и введены в учебную практику изданные ранее и оригинальные тексты всего исторического периода развития письменной культуры, работа в этом направлении не прекращалась. Ясно было, что «Историческая христоматия» как учебное руководство - вершина лингвистического источниковедения тех лет, по сути дела разработанный ученым новый жанр пособий по методике изучения церковно-славянского и древнерусского языков, причем не упрощенного, так сказать, адаптированного свойства, а имеющего высокий научно-исследовательский потенциал. Но как быть 
с теми, кто только начинает обучаться основам исторической грамматики? Для этой цели Ф. И. Буслаев принимается за новый труд, который, хотя и в сокращенном виде, давал ясное представление об эволюционном характере словесности, показывал развитие ее форм и жанров духовного и светского содержания.

Новая «Русская хрестоматия» выдержала более 10 изданий. Е. Ф. Будде в речи памяти Ф. И. Буслаева так охарактеризовал значение этого труда в контексте филологической традиции того времени:

...если бы мы в своей школьной системе преподавания все держались метода Буслаева при преподавании отечественного языка и литературы, если бы наша система осталась верна заветам Буслаева, то мы видели бы в своих учениках людей, сознательно относящихся к своей литературе, к отечественному языку и к своей родине. Христоматия Буслаева, обнимая громадный материал, вскоре, однако, обнаружила и свои недостатки при употреблении ее в средних школах: она оказалась слишком велика, и потому понадобилось составление новой, «сокращенной» Христоматии, которая с большим удобством могла бы применяться в средней школе, где русскому языку отведено было сравнительно малое количество часов на прохождение курса. Очень естественно, что новые потребности школы вызвали в свет и новое издание «Русской христоматии» Буслаева и новый учебник «Русской грамматики, сближенной с церковнославянской». Но и в этих учебниках у Буслаева осталась та же основная точка зрения, тот же метод и то же научное изложение предмета» (БуддЕ 1898: 22-23).

Итак, материалы «Исторической христоматии Ф. И. Буслаева были использованы автором для подготовки аналогичного по названию труда, предназначенного для «средних учебных заведений» и выпускавшегося на протяжении нескольких десятилетий. Он назывался так: «Русская хрестоматия. Памятники древней русской литературы и народной словесности с историческими, литературными и грамматическими объяснениями и с словарем» (см., например, БуслАЕв 1909). Четвертое издание было рекомендовано «Ученым комитетом Министерства народного просвещения как учебное пособие для употребления в гимназиях и прогимназиях, реальных училищах, учительских институтах и учительских семинариях» (БуслАЕв 1909: I). Девятое издание «просмотрено и исправлено академиком А. И. Соболевским» (БуслАЕВ 1909: I). В предисловии Ф. И. Буслаев писал, что

...в выборе статей для Хрестоматии предпочтены памятники исторического содержания, как потому, что историческое летописное направление вообще господствует в древней русской литературе, так и для того, чтобы Хрестоматия литературная, сколько возможно ближе и нагляднее знакомила учащихся с их отечественною стариною, предлагая исторические памятники тех эпох и лиц, с которыми они в общих очерках знакомятся в классе русской истории. С этою же целью распространены в примечаниях объяснения исторические, иногда приводимые собственными словами летописцев и историков, особенно Карамзина. Равномерно и из народной поэзии приведены многие былины содержания исторического (БуслАЕВ 1909: IV). 


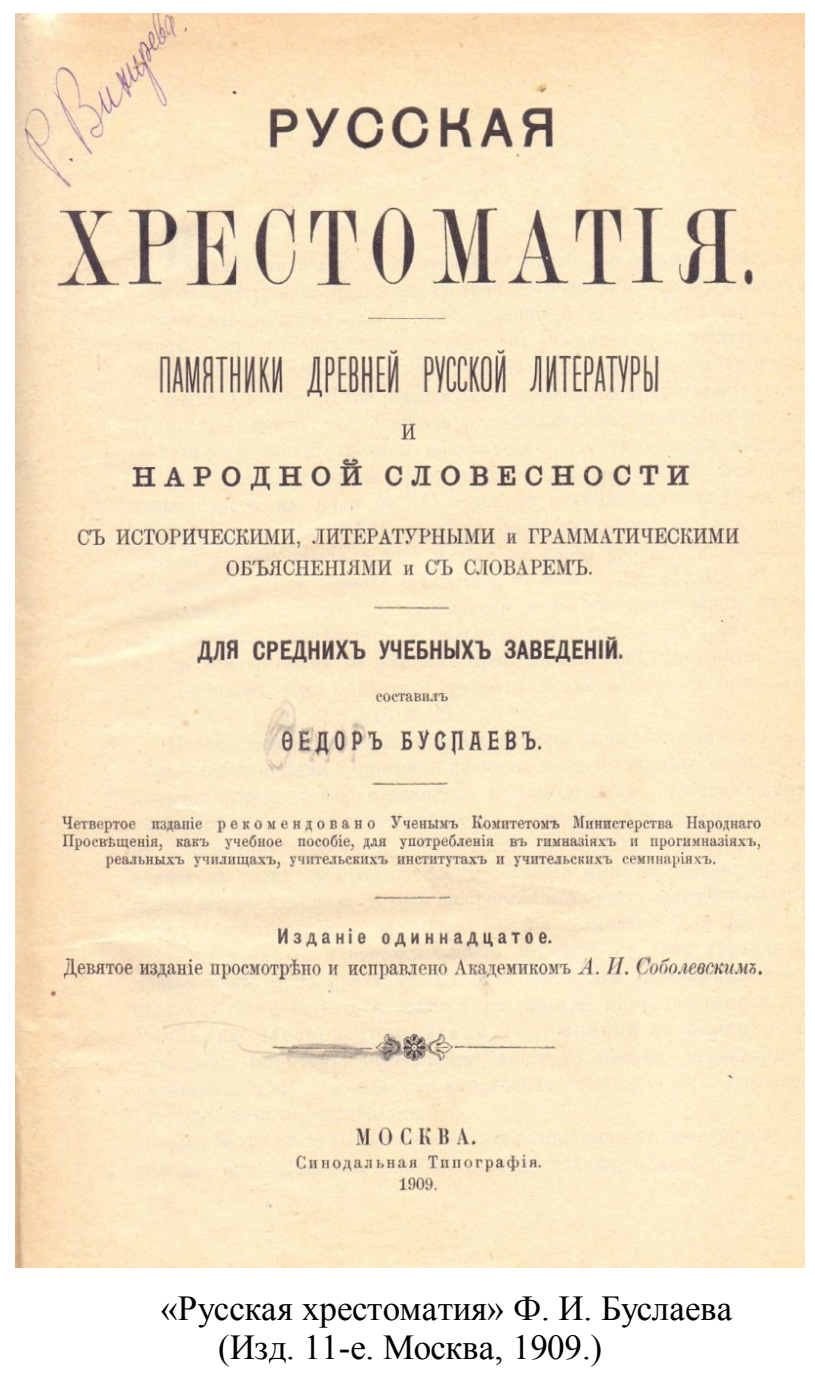

Эта сокращенная версия «Исторической христоматии» также во многом интересна учащимся с той точки зрения, что показывает существовавшую в дореволюционной школе образовательную традицию. Ее семена, когда-то посеянные Ф. И. Буслаевым в бедную почву, дали отличные всходы, зацвели, превратились в райские плоды и подрумянились на солнце русского просвещения конца XIX - начала XX века, нацеленного на высокие духовные традиции и живую связь времен.

«Русская хрестоматия» Ф. И. Буслаева начинается с публикации фрагментов «Евангелия по Остромирову списку», «слов» и житийной литературы и продолжается текстами делового содержания, апокрифическими сказаниями, «Стоглавом», «Домостроем», перепиской царских особ, песнями и 
балладами, «Путешествием Афанасия Никитина в Индию», сочинением Григория Котошихина и «Повестью о Горе-Злочастии» и т. Д. А завершается излюбленным жанром Ф. И. Буслаева - образцами «изустной народной поэзии» - эпической («Илья Муромец», «Пиры князя Владимира», «Взятие Казанского царства» и др.) и лирической (песни колыбельные, детские, свадебные, причитания, песни хороводные и подблюдные). В конце книги помещен «Словарь», в который вошли устаревшие, малопонятные, забытые вокабулы типа видокъ - «свидетель», гостьба - «торговля в чужих городах», гридь «телохранители», жадати - «чувствовать жажду», калантарь - «кольчуга без рукавов» и т. д.

Публикации фрагментов каждого памятника предшествует историко-литературный комментарий, а далее постранично автор дает лингвистические пояснения к тексту, сопровождает необходимыми филологическими деталями, отсылками к другим источникам и т. д. Значит, и «учебная» версия представляет собой вполне научный, а главное, филологически достоверный труд.

Под пером Ф. И. Буслаева ожили цветные страницы истории высокой книжности и народной словесности с их специфическими чертами, зазвучала поэзия мудрости наших предков.

Скачеть груздочекь по ельничку,

Ищеть груздочекъ бъляночку,

Не груздочекъ то скачетъ, дворянскій сынъ, Не бъляночку ищетъ, боярышню.

(БуСЛАев 1909: 460)

Таким образом, классическая «Историческая христоматия» Ф. И. Буслаева, изданная только в 1861 году, продолжила свой путь и послужила верным ориентиром не одному поколению гимназистов, студентов и учителей, познававших мир древнерусской письменной культуры и национальной словесности в ее становлении и развитии таким, каким его представлял себе создатель отечественной филологии Ф. И. Буслаев.

В Санкт-Петербургском филиале Архива РАН сохранилось интересное письмо сына Ф. И. Буслаева Владимира Федоровича академику А. А. Шахматову 1902 года. В нем содержалось известие по исправлениям в «Русской хрестоматии», «которые последуют в курсе преподавания русского языка и словесности в связи с реформой средней школы» (ПФА РАН. Ф. 134. Оп. 3. Ед. хр. № 211. Л. 1). В. Ф. Буслаев сердечно благодарил А. А. Шахматова за взятый на себя труд:

От себя лично и от имени моей матушки, с которой мы являемся сонаследниками изданий моего покойного родителя, почитаю долгом принести Вам нашу глубокую признательность и выразить особенное удовольствие, что переработке «Русской хрестоматии» в духе современных требований хотите посвятить свой досуг именно Вы, которого мой отец всегда считал одним из самых преданных и любящих его учеников и последователей (ПФА РАН. Ф. 134. Оп. 3. Ед. хр. № 211. Лл. 1-1 об.). 
Во всей нашей лингвистической практике мы не знаем ничего более интересного, полного, богатого по жанрам и историко-художественным достоинствам собрания текстов для учебной работы, чем «Историческая христоматия» Ф. И. Буслаева. Лишь только в конце 1930-х - 1940-х годов этот опыт в какой-то мере был использован С. П. Обнорским и С. Г. Бархударовым при подготовке «Хрестоматии по истории русского языка» (ОьноРскийБАРХУДАРОВ 1938, 1948 и 1949), которая заменила дореволюционную книгу Ф. И. Буслаева, ставшую библиографической редкостью и не использовавшуюся скорее по идеологическим причинам. Хотя, по нашему мнению, этот колоссальный труд ученого - не только памятник лингвистической мысли, но и историко-культурный феномен, который нисколько не устарел.

Когда приходится работать с этой книгой и рассказывать о ней студентам, то каждый раз стараешься принести ее на занятие и показать уникальный образец издательского дела. Новое поколение филологов, не знакомых со старинными изданиями, поражает все: и рифленый кожаный переплет, и бумага, и четкость шрифтов и печати, и вес, и непривычно большой формат. Все это выделяется на фоне красочных однодневок, разваливающихся после чтения и сделанных на потребу времени. «Историческая христоматия» Ф. И. Буслаева находится в моей домашней коллекции уже много лет и продолжает путь по летописным тропинкам нашей истории. Этот труд, так же как и любое другое сочинение почтенного ученого, можно назвать «филологией духа» (Никитин 2018a), впитавшей лучшие эстетические, культурные, литературно-языковые родники словесности и главный из них - любовь к языку Отечества (Никитин 2018b).

Внимание к историческому прошлому русского народа, глубокая природная связь с ним и отличное знание древних законов, обычаев и обрядов «юридического и семейного быта», как говорили раньше, позволили Ф. И. Буслаеву наряду с его талантливыми учителями и современниками А. Х. Востоковым, М. П. Погодиным, И. И. Срезневским и другими учеными заложить основы исторического изучения славяно-русской филологии, сделать эту науку главнейшим звеном в светском и духовном образовании. Многие замечательные ученики Ф. И. Буслаева: Н. С. Тихонравов, М. Н. Сперанский, В. О. Ключевский - продолжили эту традицию, воздавая должное тому, кто первым вступил на широкую дорогу научного изучения памятников словесной культуры, раскрыл их глубокий художественный смысл, заглянул в душу древнерусского автора, расшифровал причудливый слог и сделал его понятным и близким каждому человеку. Этот подвиг Ф. И. Буслаева не забыт и поныне.

\section{Сокращения}

ОР РГБ = Отдел рукописей Российской государственной библиотеки (Москва) ПФА РАН = Санкт-Петербургский филиал Архива РАН 


\section{Литература}

БудДЕ 1898 = БудДЕ Е. О заслугах Ф.И. Буслаева как ученого лингвиста и преподавателя. Речь, читанная в торжественном заседании Казанского общества археологии, истории и этнографии 28 сентября 1897 года. Казань, 1898. 1-25.

БУСЛАЕВ 1844 = БУСЛАЕВ Ф. И. О преподавании отечественного языка. Ч. 1-2. Москва, 1844.

БУСЛАЕВ 1848 = БУСЛАЕВ Ф. И. О влиянии христианства на славянский язык. Опьт истории языка по Остромирову Евангелию. Москва, 1848.

БУСЛАЕВ 1858 = БУСЛАЕВ Ф. И. Опыт исторической грамматики русского языка. Учебное пособие для преподавателей. Ч. 1. Этимология. Москва, 1858.

БУСЛАЕВ 1861 = БУСЛАЕВ Ф. И. Историческая христоматия иерковно-славянского и древнерусского языков. Составлено, на основании наставления для образования воспитанников военно-учебных заведений, высочайше утвержденного 24-го декабря 1848 года, Ф. Буслаевым. Москва, 1861.

БУСЛАЕВ 1909 = БУСЛАЕВ Ф. И. Русская хрестоматия. Памятники древней и новой литературы и народной словесности с историческими, литературными и грамматическими объяснениями и с словарем. Для средних учебных заведений. Составил Федор Буслаев. Изд. 11-е. Москва, 1909.

ГАЛАХОВ 1846-1849 = ГАЛАХОВ А. Д. (сост.) Полная русская хрестоматия. Изд. 3-е, доп. Ч. 1-3. Москва, 1846-1849.

ГАЛАХОВ $1848=$ ГАЛАХОВ А. Д. (сост.) Историческая хрестоматия цеерковно-славянского и русского языка. Москва, 1848.

Миллер 1898 = МиллеР В. Ф. Памяти Федора Ивановича Буслаева. В кн.: Памяти Федора Ивановича Буслаева. Москва, 1898. 5-42.

Никитин 2000 = Никитин О. В. Русская деловая письменность как этнолингвистический источник (на материале памятников севернорусских монастырей XVIII века). Дисс. ... канд. филол. наук. Москва, 2000.

Никитин 2009 = Никитин О. В. Василий Евдокимович Адодуров (к 300-летию со дня рождения). Русский язык в школе 2009/5: 104-110.

Никитин $2018 \mathrm{a}=$ Никитин О. В. «Филология духа». Федор Иванович Буслаев как языковая личность (к 200-летию со дня рождения). Русский язык в школе 2018/5: 79-86.

Никитин 2018b = Никитин О. В. Федор Иванович Буслаев и язык Отечества (к 200летию со дня рождения). Русская речь 2018/3: 48-56.

ОБНОРСКИЙ-БАРХУДАРОВ 1938 = ОБНОРСКИЙ С. П., БАРХУДАРОВ С. Г. Хрестоматия по истории русского языка. Пособие для студентов высших педагогических учебных заведений. Ч. 1. Ленинград-Москва, 1938.

ОБНОРСКИЙ-БАРХУДАРОВ 1948 = ОБНОРСКИЙ С. П., БАРХУДАРОВ С. Г. Хрестоматия по истории русского языка. Ч. 2. ВЫП. 2. Москва, 1948.

ОБНОРСКИЙ-БАРХУДАРОВ 1949 = ОБНОРСКИЙ С. П., БАРХУДАРОВ С. Г. Хрестоматия по истории русского языка. Ч. 2. Вып. 1. Москва, 1949.

ШАХМАТОВ $1898=$ ШАХМАТОВ А. А. Буслаев как основатель исторического изучения русского языка. В кн.: Четыре речи о Ф. И. Буслаеве, читанные в заседании Отдела Коменского 21-го января 1898 года... Санкт-Петербург, 1898. 7-16. 